\title{
Linguistic and Cultural Geography of Limitrophe Zones with Russian Language Functioning ${ }^{1}$
}

\author{
Viktor Mikhailovich Shaklein \\ Doctor of Philology, Professor, Peoples' Friendship University of Russia \\ Email:vmshaklein@bk.ru
}

\section{Doi:10.5901/mjss.2015.v6n1s2p99}

\begin{abstract}
The article deals with an actual theme of modern Russian philology - the perception of the Russian language limitrophe zone as natural territories of Russian civilization. The naturality here is understood in culturological and historical aspects considering status-quo of these territories which were formed in the late XX-early XXI centuries.
\end{abstract}

Keywords: limitrophe zone, the Russian language, Russian linguistic culture, linguistic and cultural geography.

\section{Introduction}

The concept under which the zone of the Russian language is deeply connected with the idea of keeping the influence of Russia in Europe and Asia becomes extremely popular in modern linguistics. That is why the zone of the Russian language is understood as the territory which cannot be given away, the territory which has to be defended by the modern generation in an information war (Vorontsov, 2010).

The border-line territories, where the Russian language together with the other languages is a natural language for communication, are the so-called limitrophe zones (http://www.merriam-webster.com/dictionary/limitrophe). The term 'limitrophe states' derives from French "pays limitrophes" (Calvo, 2009: 246). Because of the historical factors such territories are part of other states. Nevertheless, it is very important for Russia, for the nation development and security to control the territories, but is not the condition for its survival. All the above-mentioned is summarized in the following definition: "Limitrophe is a local segment of world geospace which undergoes equal or practically equal cultural and political influence of two or more big neighbouring states" (Gorelova, Ryabtsev, 2014). The same features are pointed out in other definitions (Tsymbursky V.L.; Khatuntsev S.V.; Kharin A.). Speaking of different types of limitrophe zones, S.B. Cohen pays special attention to regions - gateways, which are characterized by small territories and population and open to external areas. Such territories play a very important role in stabilizing of world geopolitical area, putting its elements together (Cohen, 1964).

The limitrophe Russian language zones have been formed for ages. If the certain limitrophe zone did not enter the natural territory of the nation, i.e. Russia, and kept its uncertainty, this is due to a geographical reason, for example, the accessory to a different border-line mountain chain.

There are some more specific features of limitrophe zones:

1. A limitrophe is not an independent subject of geopolitics;

2. The internal politics of the zone depends on its role in geopolitical centres opposition;

3. National and state identity of a limitrophe zone is defined by its location in a buffer zone. That is why formal recognition of their sovereignty is accompanied by lack of real recognition (Pilyaev, 2011).

\section{Discussion}

The difficulty of the modern status-quo of Russian national territories and limitrophe zones is in the fact that in the end of the $X^{\text {th }}$ century as well as the other republics of the former USSR Russia lost not only the limitrophe zones, but also a number of its people, became split. There is now a question about dividing (in theory) the borders of the Russian nation, Russian linguistic culture with its core Russian language and the state borders.

The majority of Russian population lives on the neighbour territories, forming the integrated linguistic and cultural

1 Scientific publication has been made with the support of the Ministry of Education and Science of the Russian Federation in the framework of the scientific and methodological works in 2014 № 10.9063.2014 
environment despite of the borders of the states and autonomies. The third of the population is living beyond Russia, but according to the linguistic and cultural factors and in the geopolitical aspect they are living in Russia.

The above-mentioned facts give the possibility to say that the Russians have a historically defined, stable territory to the beginning of the XXIst century. This territory can be considered irrespectively to the Russian state and the other peoples living in the borders where the Russian language dominates. The territory is much larger than it is usually determined (Baranov, 2007).

The natural factors of the territory of the Russian language are: on the South and South-West - the mountains of Eurasia, seas and deserts from the Carpathians to the Amur River (on the line the Carpathians - the Black Sea - the Crimea - the Caspian Sea - deserts and heaths of Central Asia - the Altai - the Sayans - the Amur and Ussuri). Only the river border with the Chinese civilization on the Amur and Ussuri does not have a stable geomorphological and climatic dependence, which shows its instability. On the north the natural border of the Russian language zone is the Arctic Ocean, on the east - the Pacific Ocean.

The mountains divide Eurasia into two parts: the northern part with its temperate climate, heaths, forest and arctic climatic zones and the Southern Eurasia with its warm subtropical and tropical climate. The mountain chain, deserts and southern Eurasia are not characteristic and comfortable for the Russians living zones. Eurasians, for example P. Savitsky even thought Eurasia (Northern Eurasia) to be a separate continent, separated from Asia and Europe. Such opinions are certainly too radical even for the Eurasians, though they contain geographical and historical truth.

The natural zone of the Russian language is extended by the culture of numerous peoples living in the mountain or desert and heath zones and preventing the Russians from reclamation of these territories. This zone according to all the factors taken together is more comfortable for those peoples than for the Russians, though there are regions with stable domination of the Russians, e.g. Sochi, Gelendzhik, some towns of the Northern Kazakhstan, the south of Eastern Siberia, Primorye). Nevertheless, the majority of such regions were created with the help of special migration politics, on the one hand, and displacement of native people, on the other hand. For example, in the times of Stalin deportations were made first of all from these territories. But a lot of Russian people suffered of these deportations, too. These measures helped to change the status of the territories from limitrophe zones into national territories, but despite of this they remained unstable.

In the east and north-east the natural borders of the Russian language zone are less exact. The territory of the Russian nation here is formed by the peoples and their states, which are part of European civilization. Some of them are situated on the Eastern European plain. The attempts to move the border with the Russians to the East and to enlarge of the European peoples due to eastern Ukrainians and Belorussians have variable success. Most likely, the eastern border will be defined mainly by political factors in Belorussia and the Ukraine and inside their territories. The eastern border coincides with some natural factors: sub-zero isotherms of January, i.e. severe frosty winter and constant snowpack and the landscapes alike to Russian ones.

The key borders are the eastern and southern ones as in the East and North the territory is marked by natural borders - the Arctic Ocean and the Pacific Ocean.

The territory of the Russian nation consists of four main parts:

- Eastern European plain with some neighbour territories;

- Western Siberia;

- Eastern Siberia and Far East;

- Far North of these Euroasian territories.

Speaking of the Russian part of Euroasia, under the limitrophe zones we mean the territory where Russian ethnos interests are connected with the other ones.

It is necessary to draw attention to the fact that the borders of the national territory and limitrophe zone do not coincide with the state borders of Russia. For example, the main part of the Ukraine is not a limitrophe zone, it is a territory of the Russian language functioning, apart from Western and a part of Central Ukraine. At the same time the zone of compact living of Northern Caucasian peoples is a limitrophe zone.

The main theoretic and practical problems about the USSR heritage are connected with the limitrophe zones or the question where to put the border and whether to consider the mountain chain neighbouring to the Russians to be a natural zone of the Russian language and culture. The Russian base of the territory with dominating Russian language and culture remains untouched. The Eurasians considered it necessary to include limitrophe zones into natural ones, but modern scientists are likely to exclude the border-line peoples out of the ethnic synthesis with the Russians. The flower revolutions showed that they are developing in the opposite direction. If before the end of the 1990-s the ideas of Savitsky, Vernadsky, Trubetskoy, Humilev can be taken literally, now it is clear that they have only historiographic value. The main modern theories based on their ideas are concerned mainly with deleting limitrophe zones out of the territories 
of the Russian language and culture (Tsimbarsky, 2008; Kagansky, 2003; Trenin, 2006).

The main linguistic and cultural environment of Eurasia has been kept as modern Russia together with steppe zone. The ethnic base of Eurasia - the Russians - has also been kept.

The peculiarity of the Russian nation territory is the line drawn in the centre of Eurasia in the direction of original migration of the Slavonic population from the West to the East up the Pacific Ocean.

The territory of the Russian language includes the following linguistic and cultural regions that can be considered as relatively Russian, taking into account assimilation and integration processes:

- Central Russia and Siberia including the centre of Russia up to the Ukraine in the south, Belarus in the west, Baltic countries in the north, the Urals and Eastern Siberia in the east. The Russian population in all the territories is the same from linguistic and cultural point of view despite of some regional peculiarities;

- the Ugro-Finns in all their republics can be considered as a specific Russian linguistic and cultural region slowly assimilating and integrating into the Russian ethnos;

- Prichernomorye includes the Black Sea shore, Rostov region, the Crimea, the former Novorussia (Donetsk, Zaporojye, Kherson, Nikolaev, Odessa regions, Transnistria). The peculiarity of Prichernomorye is in the specific Russian and Ukranian synthesis.

- $\quad$ the Northern Caucasus (its Russian part) includes Stavropol region and the majority of Krasnodar region, a part of Rostov region, the Russian part of Caucasian republics;

- Caucasian republics and Kalmykia apart from some regions are not natural territories of Russian linguistic culture, though they form a necessary part of the state;

- Northern Kazakhstan, Orenburg region, Nizhnee Povoljye, the south of Eastern Siberia (territories with Russian population domination);

- Eastern Ukraine and Russia and Ukraine borderline, Donetsk, Lugansk, Kharkov, Dnepropetrovsk regions. The territory is similar to Prichernomorye, but has a vivid southern specifics. The linguistic and cultural peculiarity is in dominating of Eastern Ukranians - Ukrainorussians (Russians having Ukranian linguistic features);

- Central Ukraine and Kiev, UkranianPokesye. The question of Russian character of Central Ukraine is rather doubtful, but several regions have a definite Russian identity. The Russian language in Central Ukraine has been playing a rather important role, but did not dominate;

- Belarus and separately Eastern, Western Belarus and Belorussian Polesye. The Belorussians are a specific nation, though to the great extent can be considered Russian;

- Russian Baltic states, Kaliningrad region, some cities of the Baltic states. Slavonic population has historically been living in Southern Baltia, through which one of the centers of Russian onthogenesis (Novgorod region) was created. That is why the territory is not alien for the Rusians, though they live here piecewise.

- Transnistria. Here the belonging of the most part of the population to Russian linguistic culture is the most vivid.

\section{Concluding Remarks}

In such a way to the 80-s of the XX century the main limitrophe zones with Russian language and culture domination were formed. Now these zones are considered problematic. The problem is in the fact that in the person of Russian population there the interests of Russia as a linguistic, cultural, and geopolitical unity are being oppressed.

\section{References}

Baranov S.D. Great Russian Nation: to Be or not to Be // 01 July 2007. [Online] Available: http://парламентскийклуб.pфp/index.php?option=com_content\&view=article\&id=70:2011-01-29-20-09-07\&catid=54:expert-sovet.

Calvo C. Dictionnaire Manuel de Diplomatie et de Droit International Public et Privé. The Lawbook Exchange, Ltd. 2009.

Cohen S.B. Geography and Politics in a Divided World. L.: Methuen, 1964. P. 83-85, 230-252

Gorelova G.V., Ryabtsev V.N. Imitation Modelling of a Geopolitical Zone "Black Sea Region - Caucasus - the Caspian Sea" XII AllRussia Meeting on Administration Problems. VSPU 16-19 June 2014. [Online] Available: http://vspu2014.ipu.ru/proceedings/ prcdngs/8149.pdf

Kagansky V.L. Cultural Landscape and Soviet Living Environment. Moscow, 2003.

Kharin A. The Theory of Area and Theory of Great Limitrophe. 13 August, 2013. [Online] Available: http://pluriversum.org/blogs/ Geoharin/18.php

Khatuntsev S.V. Limitrophes - Intercivilization Areas of the Old and New World // POLIS. 2011. № 2. 
Pilyaev I. From Lithuanian to Limitrophe Russia. [Online] Available: http://telegrafua.com/country/12601/print Trenin D. The End of Eurasia. Moscow, 2006.

Tsimbursky V. The Island of Russia. Criteria of Russian Identity. Moscow, 2008.

Tsymbursky V.L. People between Civilizations // The Isle of Russia. Geopolitical and Chronopolitical Papers. 1993-2006. - Moscow, 2007. - P. 212-238.

Vorontsov A.V. The Russian Language: Social and Political Context. Saint-Petersburg, 2010. [Online] Available: http://www.merriamwebster.com/dictionary/limitrophe 